\title{
Analysis of the Difference in Color Development in the Dye-binding Method Due to the Kind of Buffer Solution
}

\author{
Yuji SuZuKI \\ Department of Medical Technology, Saitama Prefectural University Junior College, \\ 820, Sannomiya, Koshigaya, Saitama 343-8540, Japan
}

\begin{abstract}
In a dye-binding method using a $\mathrm{pH}$ indicator, color development has reportedly been affected by the kind of buffer solution used in the color reagent. This phenomenon was analyzed by using a calculation based on the assumption that the anion of the buffer solution also reacts with protein. Color development decreases with increases in the anion concentration of the buffer solution and in the equilibrium constant of the reaction between the anion and protein. The differences in color development due to the kind of buffer solution can be attributed to differences in the equilibrium constant of the reaction forming the anion-protein complex and to the concentration of the anion between the buffer solutions.
\end{abstract}

(Received March 13, 2006; Accepted April 24, 2006)

\section{Introduction}

The dye-binding method based on a protein error of a $\mathrm{pH}$ indicator occurring in the presence of a protein has been widely employed for the determination of serum protein during clinical examinations. ${ }^{1-6}$ In this method, the color reagent is comprised of a dye and a buffer solution, which maintain the $\mathrm{pH}$ of the reaction mixture to be constant. Methyl orange, ${ }^{1}$ bromophenol blue, ${ }^{2}$ bromocresol green, ${ }^{3,4}$ bromocresol purple, ${ }^{5,6}$ etc. have been employed as color reagent dyes. As a buffer solution, citrate buffer, ${ }^{1,2}$ phosphate buffer, ${ }^{3}$ tartarate buffer, ${ }^{4-6}$ acetate buffer, ${ }^{5}$ etc. have been used. In the dye-binding method, the color development between the dye and protein has reportedly differed according to the kind of buffer solution used ${ }^{4,6}$ in addition to the $\mathrm{pH}$, dye and buffer concentrations. ${ }^{7}$ However, the reason why the color development differs depending on the kind of buffer solution is unclear. Thus, the author investigated the effect on the color development of the type of buffer solution, using a theoretical calculation based on the chemical equilibrium of the protein error previously reported, ${ }^{8-12}$ and then compared these calculated results with experimental results obtained by using bromocresol purple, which is widely employed in clinical examinations, as well as two kinds of buffer solutions.

\section{Experimental}

\section{Reagents}

All of the reagents were obtained from Wako Pure Chemical Industries, Ltd., Osaka, Japan, and were of the best quality available.

Buffer solutions: The citric acid/ $\mathrm{Na}_{2} \mathrm{HPO}_{4}$ buffer solution was prepared by mixing solutions of $0.1 \mathrm{~mol} \mathrm{l}^{-1}$ citric acid and 0.2 mol $1^{-1} \mathrm{Na}_{2} \mathrm{HPO}_{4}$. The acetic acid/sodium acetate buffer solution was prepared by mixing solutions of $0.2 \mathrm{~mol} \mathrm{l}^{-1}$ acetic acid and $0.2 \mathrm{~mol} \mathrm{l}^{-1}$ sodium acetate. The $\mathrm{pH}$ of the solutions was adjusted, using a Hitachi-Horiba $\mathrm{M} 8 \mathrm{pH}$ meter.
A dye solution, $1 \mathrm{mmol} \mathrm{1}^{-1}: 540 \mathrm{mg}$ of bromocresol purple (BCP) was dissolved in $10 \mathrm{ml}$ of ethanol, and then diluted to $1000 \mathrm{ml}$ with distilled water.

Color reagent: To $10.0 \mathrm{ml}$ of a dye solution, $10-90 \mathrm{ml}$ of a buffer solution was added, and then diluted to $100 \mathrm{ml}$ with distilled water.

A protein solution, $2 \mathrm{~g} \mathrm{l}^{-1}: 200 \mathrm{mg}$ of human serum albumin, was dissolved in $100 \mathrm{ml}$ of distilled water.

\section{Procedure}

A test solution was prepared by adding $2.0 \mathrm{ml}$ of a color reagent to $0.5 \mathrm{ml}$ of a protein solution. A reagent blank was prepared by mixing $2.0 \mathrm{ml}$ of the color reagent with $0.5 \mathrm{ml}$ of distilled water. Ten minutes after the reaction at $25^{\circ} \mathrm{C}$, their absorbances were recorded at $590 \mathrm{~nm}$ with a Hitachi 7011 Clinical Spectrophotometer against distilled water at $25^{\circ} \mathrm{C}$.

\section{Analysis of Dye-binding Method}

In this study, the calculation was carried out in the same manner as in previous studies ${ }^{8-12}$ based on the assumption that the anion of the buffer solution (like the dissociated dye anion) also reacts with protein to form a colorless anion-protein complex, so that the following chemical equilibria below are assumed to exist in the test solution:

$$
\begin{array}{ll}
\mathrm{HD} \rightleftharpoons \mathrm{H}^{+}+\mathrm{D}^{-} & \frac{\left[\mathrm{H}^{+}\right]\left[\mathrm{D}^{-}\right]}{[\mathrm{HD}]}=K_{\mathrm{D}}, \\
\mathrm{P}^{+}+\mathrm{D}^{-} \rightleftharpoons \mathrm{PD} & \frac{[\mathrm{PD}]}{\left[\mathrm{P}^{+}\right]\left[\mathrm{D}^{-}\right]}=K_{\mathrm{PD}}, \\
\mathrm{HM} \rightleftharpoons \mathrm{H}^{+}+\mathrm{M}^{-} & \frac{\left[\mathrm{H}^{+}\right]\left[\mathrm{M}^{-}\right]}{[\mathrm{HM}]}=K_{\mathrm{HM}}, \\
\mathrm{P}^{+}+\mathrm{M}^{-} \rightleftharpoons \mathrm{PM} & \frac{[\mathrm{PM}]}{\left[\mathrm{P}^{+}\right]\left[\mathrm{M}^{-}\right]}=K_{\mathrm{PM}},
\end{array}
$$


where $\mathrm{HD}$ is the dye, $\mathrm{D}^{-}$the dissociated dye anion, $\mathrm{P}^{+}$the unreacted protein positively charged, $\mathrm{M}^{-}$the anion of the buffer solution, PM the anion-protein complex, and PD the dye-protein complex. $K_{\mathrm{D}}$ is the dissociation constant of the dye, and $K_{\mathrm{PM}}$ and $K_{\mathrm{PD}}$ are the equilibrium constants for the reactions forming the anion-protein complex and the dye-protein complex, respectively.

When the total dye concentration, the total buffer anion concentration, and the protein concentration positively charged, are represented by $C_{\mathrm{D}}, C_{\mathrm{M}}$, and $C_{\mathrm{P}}$, respectively, we obtain the following quadratic expression for $[\mathrm{PD}]:^{12}$

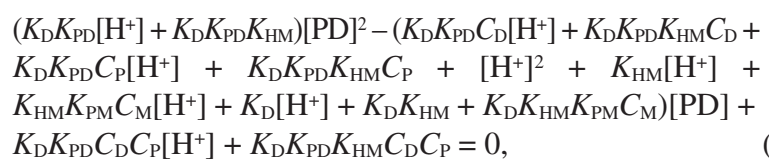

where the total protein concentration in the test solution and the mean ionization degree of the amino acid residue in a positively charged protein molecule are represented by $C_{\mathrm{X}}$ and $\alpha$, respectively, $C_{\mathrm{P}}$ is expressed as follows:

$$
C_{\mathrm{P}}=\alpha C_{\mathrm{X}}=\frac{C_{\mathrm{X}}}{1+\frac{K_{\mathrm{W}}}{K_{\mathrm{b}}\left[\mathrm{H}^{+}\right]}+\frac{K_{\mathrm{a}} K_{\mathrm{W}}}{K_{\mathrm{b}}\left[\mathrm{H}^{+}\right]^{2}}},
$$

where $K_{\mathrm{a}}$ and $K_{\mathrm{b}}$ indicate the mean dissociation constants of the acidic and basic residues, respectively, and $K_{\mathrm{W}}$ is the ionic product for water.

The absorbance of the test solution measured by a spectrophotometer was calculated as follows:

$$
\begin{aligned}
E_{\mathrm{Z}} & =E_{\mathrm{P}}-E_{\mathrm{B}}=E_{\mathrm{PD}}+E_{\mathrm{D}}-E_{\mathrm{B}}=\varepsilon_{\mathrm{PD}}[\mathrm{PD}]+\varepsilon_{\mathrm{D}}\left[\mathrm{D}_{\mathrm{P}^{-}}\right]-\varepsilon_{\mathrm{D}}\left[\mathrm{D}_{\mathrm{B}}^{-}\right] \\
& =\left(\varepsilon_{\mathrm{PD}}-\varepsilon_{\mathrm{D}} \frac{K_{\mathrm{D}}}{\left[\mathrm{H}^{+}\right]+K_{\mathrm{D}}}\right)[\mathrm{PD}] \\
& =\left\{\varepsilon_{\mathrm{D}}\left(n-\frac{K_{\mathrm{D}}}{\left[\mathrm{H}^{+}\right]+K_{\mathrm{D}}}\right)\right\}[\mathrm{PD}],
\end{aligned}
$$

where $E_{\mathrm{Z}}$ (apparent absorbance) is the absorbance of the test solution against the reagent blank, $E_{\mathrm{P}}$ the absorbance of the test solution containing the dye-protein complex and the unreacted dye anion $\left(\mathrm{D}_{\mathrm{P}}^{-}\right), E_{\mathrm{B}}$ the absorbance of the dye anion $\left(D_{\mathrm{B}}{ }^{-}\right)$in the reagent blank, $E_{\mathrm{PD}}$ the absorbance of the dye-protein complex formed, $E_{\mathrm{D}}$ the absorbance of the unreacted dye anion $\left(\mathrm{D}_{\mathrm{P}}^{-}\right)$in the test solution, and $\varepsilon_{\mathrm{PD}}$ and $\varepsilon_{\mathrm{D}}$ are the molar absorptivities of the dye-protein complex and the dye anion, respectively. $E_{\mathrm{P}}$, $E_{\mathrm{B}}, E_{\mathrm{PD}}$ and $E_{\mathrm{D}}$ are measured against distilled water. $n$ is the ratio of the molar absorptivities of the dye-protein complex and the dye anion $\left(=\varepsilon_{\mathrm{PD}} / \varepsilon_{\mathrm{D}}\right)$.

$E_{\mathrm{Z}}$ at an arbitrary $\mathrm{pH}$ can be obtained by calculating the concentration of PD by Eq. (5), and then substituting this value into Eq. (6), giving arbitrary values to the variables $\mathrm{p} K_{\mathrm{D}}, K_{\mathrm{PD}}$, $K_{\mathrm{HM}}, K_{\mathrm{PM}}, K_{\mathrm{a}}, K_{\mathrm{b}}, C_{\mathrm{D}}, C_{\mathrm{M}}, C_{\mathrm{X}}, \varepsilon_{\mathrm{D}}$ and $n$, as shown below. The $\mathrm{p} K_{\mathrm{D}}$ value of the dye was 6.3 , and the $K_{\mathrm{PD}}$ value of the dyeprotein complex was $10^{7}$. The $K_{\mathrm{HM}}$ value was $10^{-3}$, and the $K_{\mathrm{PM}}$ value of the anion-protein complex varied from $10^{2}$ to $10^{3}$. The mean dissociation constants of the side chains of the amino acid residue in the protein molecule were $K_{\mathrm{a}}=10^{-8}$ and $K_{\mathrm{b}}=10^{-2}$, respectively. The total dye concentration was $8 \times 10^{-5} \mathrm{~mol} \mathrm{l}^{-1}$, the anion concentration varied from 0.02 to $0.14 \mathrm{~mol} \mathrm{l}^{-1}$; the total protein concentration ranged from $3.0 \times 10^{-6}$ to $3.0 \times 10^{-5}$ mol $1^{-1}$. Since the $n$ value, semiempirically obtained, was $n=$ 0.49 in the reaction of $\mathrm{BCP},{ }^{11}$ the calculation was carried out using $n=0.5$. The absorptivity $\left(\varepsilon_{\mathrm{D}}\right)$ of the dye anion was $7 \times$ $10^{4} 1 \mathrm{~mol}^{-1} \mathrm{~cm}^{-1}$.

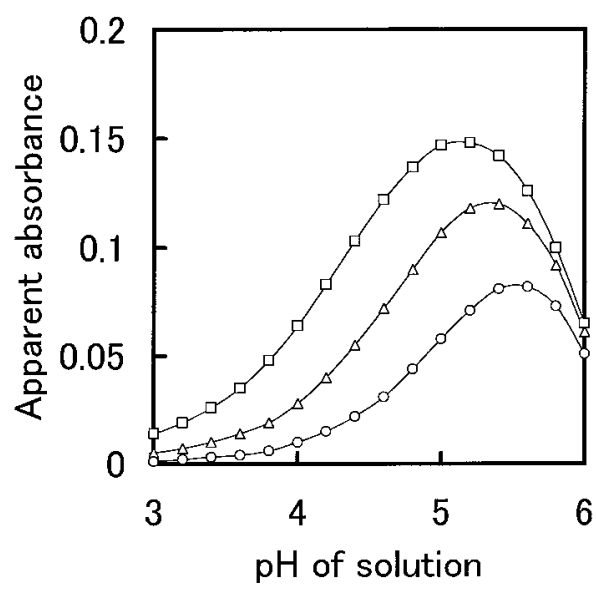

Fig. 1 Relationship between the apparent absorbance and the $\mathrm{pH}$ when the $K_{\mathrm{PM}}$ value varied (calculated result). Calculation conditions: $\mathrm{p} K_{\mathrm{D}}=6.3 ; K_{\mathrm{PD}}=10^{7} ; K_{\mathrm{HM}}=10^{-3} ; C_{\mathrm{D}}=8 \times 10^{-5} \mathrm{~mol} \mathrm{1}^{-1}$; $C_{\mathrm{X}}=5.8 \times 10^{-6} \mathrm{~mol} \mathrm{l}^{-1} ; C_{\mathrm{M}}=0.08 \mathrm{~mol} \mathrm{l}^{-1} ; \varepsilon_{\mathrm{D}}=7 \times 10^{4} 1 \mathrm{~mol}^{-1} \mathrm{~cm}^{-1} ; n$ $=0.5 ; \square, K_{\mathrm{PM}}=10^{2} ; \triangle, K_{\mathrm{PM}}=10^{2.5} ; \mathrm{O}, K_{\mathrm{PM}}=10^{3}$.

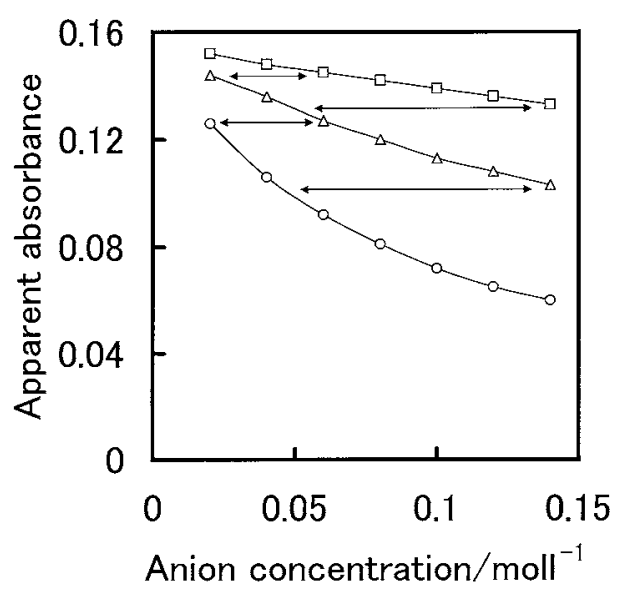

Fig. 2 Relationship between the apparent absorbance and the buffer anion concentration when the $K_{\mathrm{PM}}$ value varied (calculated result). Calculation conditions: $\mathrm{p} K_{\mathrm{D}}=6.3 ; K_{\mathrm{PD}}=10^{7} ; K_{\mathrm{HM}}=10^{-3} ; C_{\mathrm{D}}=8 \times$ $10^{-5} \mathrm{~mol} \mathrm{l}^{-1} ; C_{\mathrm{X}}=5.8 \times 10^{-6} \mathrm{~mol} \mathrm{l}^{-1} ; \varepsilon_{\mathrm{D}}=7 \times 10^{4} 1 \mathrm{~mol}^{-1} \mathrm{~cm}^{-1} ; n=0.5$; $\mathrm{pH}=5.4 ; \square, K_{\mathrm{PM}}=10^{2} ; \triangle, K_{\mathrm{PM}}=10^{2.5} ; \mathrm{O}, K_{\mathrm{PM}}=10^{3}$.

\section{Results}

\section{Calculated results}

The anion concentration contained in the buffer solution affects the amount of dye-protein complex formed and its apparent absorbance, as described in a previous paper. ${ }^{12}$ Namely, as the formation of the dye-protein complex decreases by increasing the anion concentration, the apparent absorbance, i.e., the color development, decreases. When the kind of anion is different from the kind of buffer solution used, the ion radius and the ionic valence differ with the kind of anion. Therefore, the bonding strength between the anion and the protein is thought to differ with the kind of buffer solution. The difference in the bonding strength of the anion to the protein causes a difference in the equilibrium constant of the reaction between anion and the protein. Thus, the apparent absorbance was calculated, changing the equilibrium constant of the reaction. Figure 1 indicates the relationship between the 


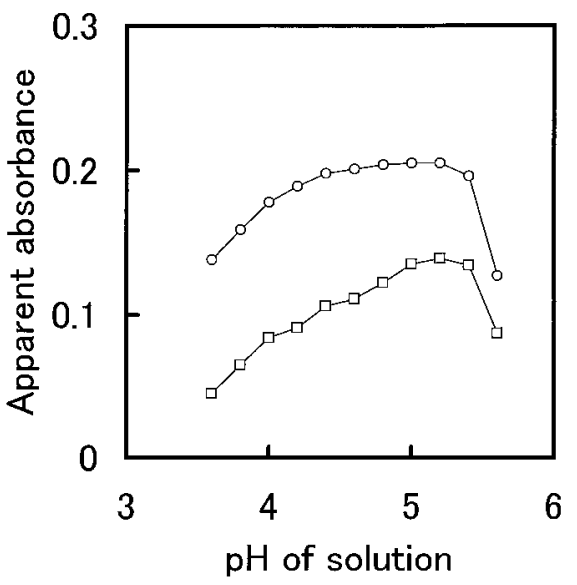

Fig. 3 Relationship between the apparent absorbance and the $\mathrm{pH}$ when two kinds of BCP color reagent containing different buffer solutions were used. The final dye and protein concentrations were $C_{\mathrm{D}}=8 \times 10^{-5} \mathrm{~mol} \mathrm{l}^{-1}$ and $C_{\mathrm{X}}=5.8 \times 10^{-6} \mathrm{~mol} \mathrm{l}^{-1}$, respectively. Color reagents were prepared by mixing $10 \mathrm{ml}$ of a $1 \mathrm{mmol} \mathrm{l}^{-1} \mathrm{BCP}$ solution with $90 \mathrm{ml}$ of a buffer solution. O, Acetic acid/sodium acetate buffer solution; $\square$, citric acid/ $\mathrm{Na}_{2} \mathrm{HPO}_{4}$ buffer solution.

apparent absorbance and the $\mathrm{pH}$ when the equilibrium constant varies. As the equilibrium constant increases, the apparent absorbance significantly decreases over a wide range of $\mathrm{pH}$ values, and the $\mathrm{pH}$ at which its maximum absorbance appears shifts to a higher value. Figure 2 shows the relationship between the apparent absorbance and the concentration of the buffer anion when the $K_{\mathrm{PM}}$ value varies. When the $K_{\mathrm{PM}}$ values of each buffer are different, the apparent absorbances of each buffer also differ, even at the same concentration of the buffer anion. However, if the difference in the $K_{\mathrm{PM}}$ value is small, the same apparent absorbance can be obtained by selecting a different buffer concentration for each buffer. For example, the arrows $(\uparrow)$ shown in Fig. 2 indicate each buffer concentration at which their apparent absorbances become equal to each other. The degree of the decrease in the apparent absorbance grows greater as the $K_{\mathrm{PM}}$ value increases. Furthermore, the $K_{\mathrm{PM}}$ value affects the linearity of the calibration curve. The calibration curve approaches a straight line as the $K_{\mathrm{PM}}$ value decreases. Thus, the color development is found to be changed by both the anion concentration and the equilibrium constant of the reaction.

\section{Experimental results}

The effect on the color development of the kind of buffer solution in the color reagent was examined using citric acid/ $/ \mathrm{Na}_{2} \mathrm{HPO}_{4}$ and acetic acid/sodium acetate buffer solutions. The absorption spectra of the colored product formed during the color reaction between human serum albumin and $\mathrm{BCP}$ were examined in the presence of the two different buffer solutions. Although the apparent absorbance in the presence of the acetic acid/sodium acetate buffer solution was higher than that in the presence of the citric acid/ $\mathrm{Na}_{2} \mathrm{HPO}_{4}$, there was no difference in the absorption maximum wavelength, even when the kind of buffer solution in the color reagent was different. Consequently, the difference in the apparent absorbance in the color reagents containing different buffer solutions was not caused by a shift in the absorption maximum wavelength, but by the difference in the kind of buffer solution used. Figure 3 shows the relationship between the apparent absorbance and the $\mathrm{pH}$ when two kinds of different buffer solutions were used. The

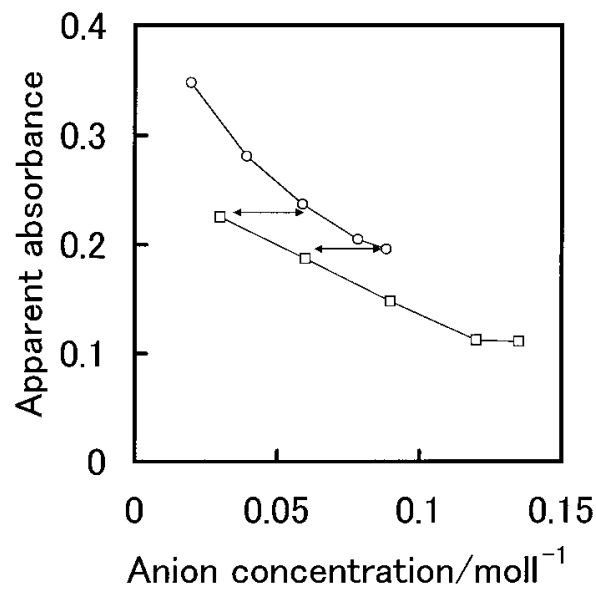

Fig. 4 Relationship between the apparent absorbance and the buffer anion concentration in the color reagent. The final dye and protein concentrations were $C_{\mathrm{D}}=8 \times 10^{-5} \mathrm{~mol} \mathrm{l}^{-1}$ and $C_{\mathrm{X}}=5.8 \times 10^{-6} \mathrm{~mol} \mathrm{l}^{-1}$, respectively. Measurements were performed at $\mathrm{pH}$ 4.6. O, Acetic acid/sodium acetate buffer solution; $\square$, citric acid/ $/ \mathrm{Na}_{2} \mathrm{HPO}_{4}$ buffer solution.

apparent absorbance in the presence of the acetic acid/sodium acetate buffer solution was higher than that in the presence of the citric acid/ $\mathrm{Na}_{2} \mathrm{HPO}_{4}$ buffer solution. In this comparison, the anion concentration was higher in the buffer solution of citric acid/ $\mathrm{Na}_{2} \mathrm{HPO}_{4}$ than in that of acetic acid/sodium acetate. Since the apparent absorbance was thought to be affected by the anion concentration from the calculation result, the color development was measured using the diluted buffer solution. When the diluted citric acid/ $\mathrm{Na}_{2} \mathrm{HPO}_{4}$ buffer solution was used, the apparent absorbance increased and became equal to that in the acetic acid/sodium acetate buffer solution, as shown in Fig. 4. The calibration curve was more linear in the presence of the buffer solution of acetic acid/sodium acetate than in that of citric acid/ $\mathrm{Na}_{2} \mathrm{HPO}_{4}$. Thus, the experimental results largely agreed with those estimated by the calculation.

\section{Discussion}

In designing a dye-binding method using a $\mathrm{pH}$ indicator, Okamura examined the effect on the color development of the kind of buffer solution added to the BCP color reagent, and reported that the color development by the citrate buffer solution which is tricarboxylic acid was lower than that by succinate and tartarate buffer solutions, which are dicarboxylic acid, and there was no difference between the dicarboxylic acids. ${ }^{4}$ Doumas also examined the relationship between color development and the kind of buffer solution, using malonate, tartarate and succinate buffer solutions, and observed that the color development differed with the kind of buffer solution, reaching a maximum in the presence of the succinate buffer solution. ${ }^{3}$

In this study, it was estimated by our calculation that the formation of the dye-protein complex and the apparent absorbance decreased when the anion concentration derived from the buffer solution increased. In addition, it was concluded that the larger is the equilibrium constant of the reaction forming the anion-protein complex, the greater is the degree of the decrease in the apparent absorbance. In other words, these calculated results show that in the presence of different buffer solutions, even if the $\mathrm{pH}$ of the color reagents is 
equal, a difference in the apparent absorbance occurs. In experiments using the acetic acid/sodium acetate and citric acid/ $/ \mathrm{Na}_{2} \mathrm{HPO}_{4}$ buffer solutions, when the buffer solution preparedinitially was used as is, without dilution, the color development in the presence of the former was higher than that in the presence of the latter. As can be seen from Fig. 4, this result is not explained only by the difference in the anion concentration in both the buffer solutions, indicating that the binding of the acetate ion to human serum albumin is weaker than that of the citrate ion or the hydrogen phosphate ion to human serum albumin. The magnitude of the binding of the anion to the positively charged protein is thought about as follows. Because the anion binds to the protein by the electrostatic interaction, its bonding strength is considered to be proportional to the number of charges of the anion. Therefore, since the number of charges of the acetate ion is less than those of the hydrogen phosphate and the citrate ions, the bonding strength of the former may be smaller than those of the latter. From this, the $K_{\mathrm{PM}}$ value of the acetate ion may be smaller than those of the hydrogen phosphate and the citrate ions. If this is correct, the color development and the calibration curve in the presence of the acetic acid/sodium acetate buffer solution are expected to be higher and more linear than those in the presence of the citric acid/ $/ \mathrm{Na}_{2} \mathrm{HPO}_{4}$ buffer solution, respectively; these presumptions coincided with the experimental facts. From these results, it is concluded that the phenomenon of color development differing with the kind of buffer solution used is attributable to differences in the anion concentration of the color reagent and the equilibrium constant of the reaction between the anion and the protein.

\section{References}

1. J. S. Bracken and I. M. Klotz, Am. J. Clin. Pathol., 1953, 23, 1055 .

2. P. G. Scheurlen, Clin. Chim. Acta, 1959, 4, 760.

3. F. L. Rodkey, Clin. Chem., 1965, 11, 478.

4. B. T. Doumas, W. A. Watson, and H. G. Biggs, Clin. Chim. Acta, 1971, 31, 87.

5. P. Carter, Microchem. J., 1970, 15, 531.

6. K. Okamura, Rinsho Kensa, 1974, 18, 646.

7. Y. Suzuki, Bunseki Kagaku, 2003, 52, 939.

8. Y. Suzuki, J. Anal. Bio-Sc., 2001, 24, 150.

9. Y. Suzuki, Anal. Sci., 2001, 17, 1263.

10. Y. Suzuki, J. Anal. Bio-Sc., 2003, 26, 441.

11. Y. Suzuki, Anal. Sci., 2004, 20, 1259.

12. Y. Suzuki, Anal. Sci., 2005, 21, 83. 